International Journal of Engineering \& Technology, 7 (4) (2018) 2051-2057
International Journal of Engineering \& Technology
SPC
Website: www.sciencepubco.com/index.php/IJET
doi: $10.14419 /$ ijet.v7it.16064
Research paper

\title{
Significant effects of cementitious materials on strength gain properties of concrete with partial replacement of fine aggregate by quarry dust
}

\author{
S. Suganya ${ }^{1 *}$, V. Rajkumar ${ }^{1}$ \\ ${ }^{1}$ APh. D. Research Scholar \& b Associate Professor Department of Civil Engineering Government College of Engineering, \\ Salem - 636011, Tamil nadu, India \\ *Corresponding author E-mail: suganya.sankaran16@gmail.com
}

\begin{abstract}
Concrete incorporates large amount of natural resource as aggregates with cement and water. Cement production consumes huge energy and causes about $7 \%$ of total greenhouse gas emission in the world. It has been strived to provide better quality in concrete using waste by-products from industries so that natural resources are used in an efficient manner and thereby the environment is protected from waste deposits. Hence, mineral admixtures like fly ash and micro silica can be used to overcome these issues. The demand for river sand is getting increased day by day, which affects its constant supply. Under these circumstances use of quarry dust becomes inevitable. The usage of fly ash in the concrete leads to strength gain only at later stages. In order to obtain strength during the early stage, micro silica is added as a partial replacement of cement. The properties of fly ash, micro silica and quarry dust were studied. Fly ash (0-40\%) and micro silica $(0-15 \%)$ are used as a partial replacement for cement and quarry dust (50\%) as that for river sand by mass. Mechanical properties of the concrete containing hybrid mineral admixtures and quarry dust are studied systematically.
\end{abstract}

Keywords: Fly Ash; Micro Silica; Quarry Dust; Super Plasticizer; Strength Gain Properties.

\section{Introduction}

Concrete plays an important role in the development of infrastructure like industrial structures, buildings, bridges and highways etc., leading to invent cementing materials that are cheaper than Portland cement. Portland cement, already being a very expensive material constitutes a substantial part of the total construction cost of any project and the situation has further been aggravated by the energy crisis, which has further increased the cost of production of Portland cement. Therefore, it is of current importance for a country to explore and develop cementitious materials cheaper than Portland cement.

Industrial wastes, such as micro silica, blast furnace slag, fly ash are being used as supplementary cement replacement materials to reduce the cost as well as to control the $\mathrm{CO}_{2}$ emission that occurs during production of Portland Cement.

Fly ash, which is also called "pulverized fuel ash" in the United Kingdom, is one of the residues produced by coal combustion, that consists of the fine particles that are discharged from the boiler with the flue gases.

Micro silica, an ultrafine powder collected as a by-product of the silicon and ferrosilicon alloy production can be used as partial replacement of cement, along with fly ash. Micro silica, which mainly constitutes amorphous $\mathrm{SiO}_{2}$, acts as a reactive pozzolan which gives high strength and durability properties at early age, when used in concrete. It's very translucent particles with a surface area values around 13,000 to $30,000 \mathrm{~m}^{2} / \mathrm{kg}$ and the particles are roughly 100 times smaller, when compared to average cement particle. Hence, it is used to enhance the properties of concrete because of its highest fineness and rich silica content.
Quarry dust is made by crushing aggregate and segregate for required sizes to be used as a fine aggregate. During the process of crushing, the stone have irregular shapes. Due to irregular shape of the aggregates there is a better packing among the particles thereby reducing the voids in concrete.

The effects of more water to binder ratio and improper compaction defects lead to undesirable properties such as honey combing, segregation, voids, capillarity, etc., which can be reduced by the use of quarry dust. Due to rough texture and angular shape of crushed stone dust the concrete becomes low workable, but on the other hand there is good bonding among the ingredients as compared to that of the conventional concrete.

The use of fly ash improves the workability of concrete. The density and air content of the concrete mix are generally unaffected with the use of fly ash. The strength gain properties of concrete decreases as the amount of fly ash increases. The rate of strength development is related to the w/c ratio and the percentage of fly ash content in the concrete mix. Modulus of Elasticity of fly ash concrete reduces with the increase of fly ash percentages. Shrinkage of fly ash concrete mix is similar to the conventional mix. RCPT test results indicate lower permeability of fly ash concrete than the conventional concrete, thus proving to be durable [1].

It was observed that fly ash substantially enhances the post-peak compressive behavior of concrete, with a comparatively smaller slope in the descending part of the stress-strain curve. Low volumes of fly ash promoted the tensile strength of concrete. High volume fly ash concrete exhibited slightly lower tensile strength, but higher values of crack tip opening displacement and final midspan deflection in the fracture tests [2].

The usage of silica fume increased the hardended properties and modulus of elasticity of concrete for various mixes. However, the 
addition of steel fiber into concrete significantly improves the toughness of high strength concrete. As the percentage of fibres is increased, the toughness also increases, which is due to the increased aspect ratio. It was also noted that the toughness of high strength fibre reinforced concrete depends on the supplimentary materials like silica fume [3].

Additionally, it is well understood that silica fume, due to high pozzolanic activity, is a necessary material in producing high strength concrete. However, it also helps the concrete to have a more brittle behaviour[4].

The micro silica added concrete can produce less permeable and high strength concrete. The addition of micro silica reduces the workability of the concrete. The use of micro silica increases the compressive strength and it depends on the replacement levels. The tensile and flexural strength of the micro silica concrete is similar to that of the conventional concrete. Addition of micro silica increases the bond strength of concrete. The modulus of elasticity of the micro silica concrete is equal to that of the conventional concrete [5].

Micro silica, being a byproduct of the smelting process from the silicon and ferrosilicon industry, has become an attractive alternative in the utilization of industrial wastes. It was found out that silica fume affects the thickness of transition phase in mortars and the degree of the orientation of the calcium hydroxide crystals The hydration of cement is stimulated by adding silica fume. The chloride-ion diffusion is significantly decreased and the long-term corrosion resistance is enhanced by the use of silica fume [6].

The flexural strength of concrete with $25 \%$ and $100 \%$ quarry dust were observed to be $2 \%$ and $4.3 \%$ higher than the conventional concrete respectively. Regression analysis was carried out and the empirical formulas were used to obtain the quarry dust concrete. It was also noted that the flexural strength of concrete is enhanced when quarry dust is incorporated [7].

In the present research work, the mechanical and durability properties of concrete specimens with and without fly ash and micro silica addition were experimentally assessed.

\section{Experimental program}

\subsection{Cement}

Fresh OPC 43 grade cement without any lumps was used. Testing of cement was done in accordance with IS: 8112-1989 [8]. The various tests result values of cement are given in Table 1.

Table 1: Properties of Cement

\begin{tabular}{llll}
\hline S. No & Characteristics & $\begin{array}{l}\text { Values ob- } \\
\text { tained }\end{array}$ & Standard values \\
\hline 1 & Standard Consistency Test & $31 \%$ & $26 \%-32 \%$ \\
2 & Specific Gravity & 3.15 & $3.12-3.19$ \\
3 & Fineness test & $2930 \mathrm{~cm}^{2} / \mathrm{g}$ & $>2250 \mathrm{~cm}^{2} / \mathrm{g}$ \\
4 & Initial Setting Time & $32 \mathrm{~min}$ & $\begin{array}{l}\text { Not less than } \\
30 \mathrm{~min}\end{array}$ \\
& & & Not more than \\
5 & Final Setting Time & $260 \mathrm{~min}$ & $600 \mathrm{~min}$ \\
6 & Soundness & $3 \mathrm{~mm}$ & Less than $10 \mathrm{~mm}$ \\
\hline
\end{tabular}

\subsection{Fly ash}

The Class F fly ash used in this work was obtained from Mettur Thermal Power Station which is located in Salem district -Tamil Nadu, India. The test results on fly ash are mentioned in Table 2.

Table 2: Properties of Fly Ash

\begin{tabular}{lll}
\multicolumn{2}{c}{ Table 2: Properties of Fly Ash } \\
\hline S. No & Characteristics & Values obtained \\
\hline 1 & Class & F \\
2 & Specific gravity & 2.23 (within standard val- \\
3 & Colour & ues of 1.9 to 2.8) \\
4 & Moisture content & Grey \\
\hline
\end{tabular}

\subsection{Micro silica}

Micro silica named Elkem- micro silica 920 D was used in this work, confirming to ASTM-C (1240-2000) [9]. Micro silica is utilized as a partial replacement of cement and the properties of micro silica values are given in Table 3 .

Table 3: Properties of Micro Silica

\begin{tabular}{llll}
\hline S. No & Characteristics & Values obtained & Standard values \\
\hline 1 & Bulk density & $576 \mathrm{~kg} / \mathrm{m}^{3}$ & 130 to $600 \mathrm{~kg} / \mathrm{m}^{3}$ \\
2 & Specific gravity & 2.20 & 2.2 to 2.3 \\
3 & Size & $0.1 \mu \mathrm{m}$ & Less than $1 \mu \mathrm{m}$ \\
4 & Moisture content & Nil & - \\
5 & $\mathrm{SiO}_{2}$ & $90-96 \%$ & $85-97 \%$ \\
\hline
\end{tabular}

\subsection{Coarse aggregate}

Locally available coarse aggregates having a maximum size of 20 $\mathrm{mm}$ were used in the present work. Testing of coarse aggregates was done as per IS: 383-2016 [10]. The various test results conducted on coarse aggregates are given in Table 4

Table 4: Properties of Coarse Aggregate

\begin{tabular}{llll}
\hline S. No & Characteristics & Values & Standard values \\
\hline 1 & Type & Crushed & - \\
2 & Maximum size & $20 \mathrm{~mm}$ & - \\
3 & Specific gravity & 2.7 & $2.6-2.9$ \\
4 & Total water absorption & $0.3 \%$ & $0.1 \%$ to $2 \%$ \\
5 & Fineness Modulus & 7.32 & 6.5 to 8 \\
6 & Impact value & $22 \%$ & - \\
7 & Crushing value & $17 \%$ & - \\
\hline
\end{tabular}

\subsection{Fine aggregate}

In the present investigation normal river sand was used as fine aggregate, which is available in Salem, extracted from Cauvery River near Musiri. The fine aggregate was screened at site to remove deleterious materials and tested as per procedure given in IS $2386-1963$ [11]. The various test results conducted on river sand are reported in Table 5.

Table 5: Properties of Fine Aggregate

\begin{tabular}{llll}
\hline S. No & Characteristics & Results & Standard values \\
\hline 1 & Grading Zone & Zone II & - \\
2 & Specific Gravity & 2.47 & 2.3 to 2.7 \\
3 & Water absorption & $0.5 \%$ & Not greater than $3 \%$ \\
4 & Fineness Modulus & 2.69 & 2.2 to 2.8 \\
5 & Moisture Content & Nil & - \\
\hline
\end{tabular}

\subsection{Quarry dust}

Quarry dust passing through IS sieve $2.36 \mathrm{~mm}$ and conforming to grading zone II and as per IS: 383-2016 [10] was used. The Properties of quarry dust values are given in Table 6 .

Table 6: Properties of Quarry Dust

\begin{tabular}{llll}
\hline S. No & Characteristics & Results & Standard values \\
\hline 1 & Specific gravity & 2.52 & 2.5 to 2.9 \\
2 & Water absorption & $2 \%$ & 2 to $4 \%$ \\
3 & Fineness modulus & 2.701 & 2.6 to 3 \\
4 & Moisture content & Nil & - \\
5 & Grading zone & Zone II & - \\
\hline
\end{tabular}

\subsection{Water}

Potable tap water available in laboratory with $\mathrm{pH}$ value of 7 and conforming to the requirements of IS: 456-2000 [12] was used for mixing concrete and curing the specimens for various mixes of concrete.

\subsection{Mix proportions}

M30 grade concrete was used for the experimental works, which is being used in structural concrete in foundation works to stand against aggressive conditions. The mix design for OPC concrete was confirming to IS 10262: 2009 [13] and SP 430 and used for 
all mixes of concrete. The addition of fly ash and micro silica in shown in Table 7. percentage of cement, relevant to the respective concrete mix is

Table 7: Proportions of Hybrid Admixtures with Cement

\begin{tabular}{llll}
\hline Mix ID & Cement (\%) & Fly Ash (\%) & Micro silica (\%) \\
\hline CC & 100 & 0 & 0 \\
F1 & 100 & 0 & 0 \\
F2 & 90 & 10 & 0 \\
F3 & 80 & 20 & 0 \\
F4 & 70 & 30 & 0 \\
F5 & 60 & 40 & 0 \\
S1 & 90 & 10 & 0 \\
S2 & 80 & 15 & 5 \\
S3 & 70 & 20 & 10 \\
S4 & 60 & 25 & 15 \\
\hline
\end{tabular}

Table 8: Mix Proportions for M30 Grade of Concrete

\begin{tabular}{|c|c|c|c|c|c|c|c|c|c|}
\hline Mix Id & $\begin{array}{l}\text { Cement } \\
\left(\mathrm{kg} / \mathrm{m}^{3}\right)\end{array}$ & Fly ash & Micro silica & Coarse aggregate & Fine aggregate & Quarry dust & $\mathrm{w} / \mathrm{c}$ ratio & Super Plasticizer (\%) & $\begin{array}{l}\text { Slump } \\
\text { value } \\
(\mathrm{mm})\end{array}$ \\
\hline $\mathrm{CC}$ & 390 & 0 & 0 & 1206 & 648 & 0 & 0.43 & 1.5 & 72 \\
\hline $\mathrm{F} 1$ & 390 & 0 & 0 & 1206 & 324 & 324 & 0.43 & 1.5 & 74 \\
\hline $\mathrm{F} 2$ & 351 & 39 & 0 & 1206 & 324 & 324 & 0.43 & 1.5 & 75 \\
\hline F3 & 312 & 78 & 0 & 1206 & 324 & 324 & 0.43 & 1.5 & 78 \\
\hline $\mathrm{F} 4$ & 273 & 117 & 0 & 1206 & 324 & 324 & 0.43 & 1.5 & 79 \\
\hline F5 & 234 & 156 & 0 & 1206 & 324 & 324 & 0.43 & 1.5 & 73 \\
\hline $\mathrm{S} 1$ & 351 & 39 & 0 & 1206 & 324 & 324 & 0.43 & 1.5 & 66 \\
\hline S2 & 312 & 58.5 & 19.5 & 1206 & 324 & 324 & 0.43 & 1.5 & 67 \\
\hline S3 & 273 & 78 & 39 & 1206 & 324 & 324 & 0.43 & 1.5 & 69 \\
\hline $\mathrm{S} 4$ & 234 & 97.5 & 58.5 & 1206 & 324 & 324 & 0.43 & 1.5 & 65 \\
\hline
\end{tabular}

Fly ash was used as partial replacement of cement by $10 \%, 20 \%$, $30 \%$ and $40 \%$ using modified replacement method. In this combination, cementitious materials were more than that used in conventional concrete. Quarry dust was used as partial replacement of river sand in conventional mix by 50\% in mass. Again in each fly ash mix concrete micro silica was used as partial replacement to cement by $5 \%, 10 \%, 15 \%$ and $20 \%$ by mass at different curing days. Table 8 gives the mix proportion used in this study.

\subsection{Testing procedure}

Compressive strength of hardened concrete was measured at the ages of 7, 28 and 56 days on $150 \mathrm{~mm}$ cubic specimens ( 3 specimens in each case). The test was carried out to obtain the compressive strength by using Compression Testing Machine (CTM) of capacity 100 tons and the respective snapshot is shown in Fig. 1 .

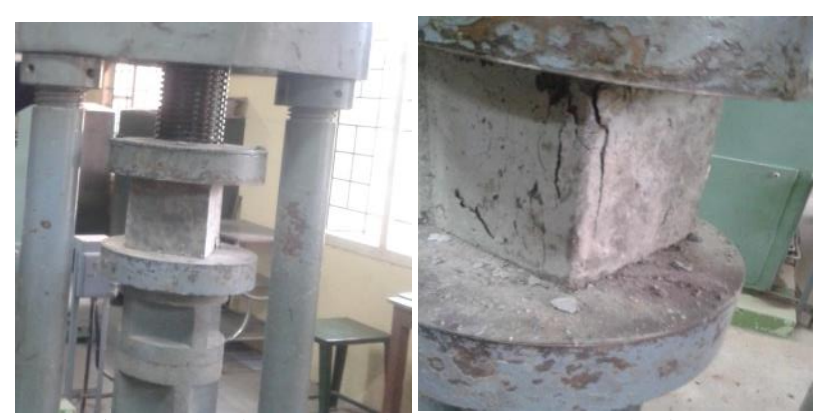

Fig. 1: Snapshot for Testing of Compressive Strength of Concrete.

Split tensile strength on $100 \times 200 \mathrm{~mm}$ cylindrical specimens and flexural strength on $100 \times 100 \times 500 \mathrm{~mm}$ beam specimens were tested at 28 days. The tests were carried out conforming to IS 5161959 [14]. The prism for flexure was tested using Universal Testing Machine (UTM) of capacity 100 tons.

Bond strength (pull out) test was carried out with a cylindrical specimen in which steel bar is embedded as shown in Fig. 2.

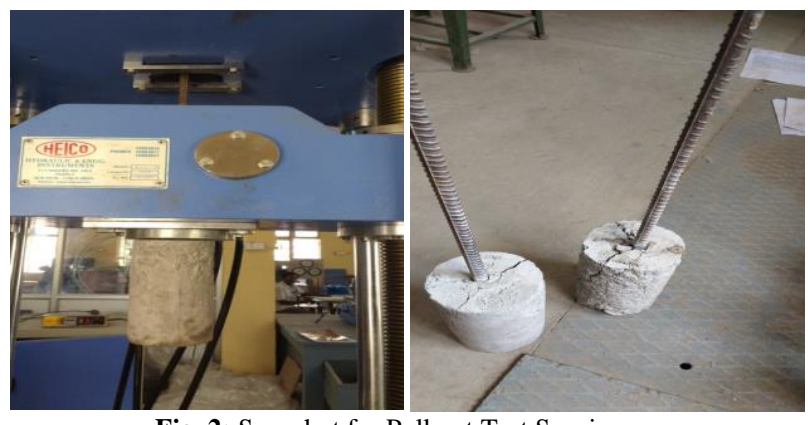

Fig. 2: Snapshot for Pull out Test Specimens.

Bond stress can be calculated by using the formula:

Bond stress $=\frac{P}{\pi \mathrm{dl}}\left(\mathrm{N} / \mathrm{mm}^{2}\right)$

Where, $\mathrm{P}=$ Ultimate load $(\mathrm{N})$

$\mathrm{d}=$ Diameter of the specimen $(\mathrm{mm})$

$\mathrm{l}=$ Embedded length of the specimen $(\mathrm{mm})$

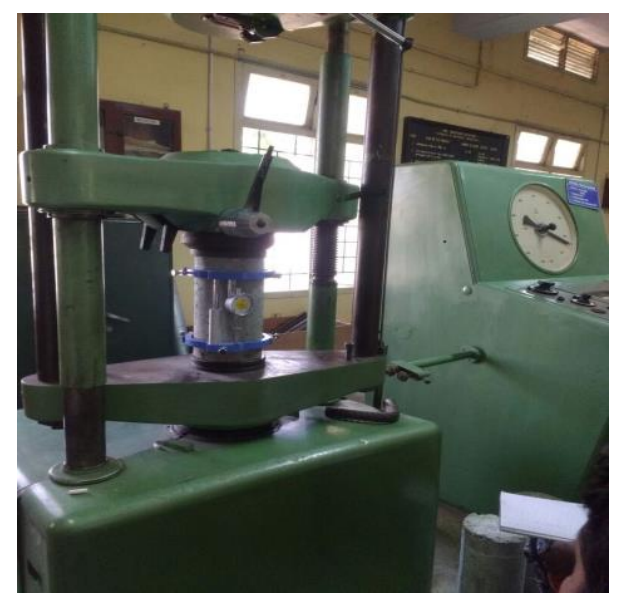

Fig. 3: Snapshot for Modulus of Elasticity of Concrete.

Other tests such as test for modulus of elasticity (fig. 3.), water permeability test and rapid chloride permeability test were also conducted, as per standard specifications. 


\section{Results and discussions}

\subsection{Compressive strength of concrete}

Results of fresh and hardened concrete containing hybrid mineral admixtures and quarry dust as a partial replacement of cement fine aggregate respectively are discussed below.
It can be noted that the $\mathrm{F} 3$ specimen (20\% fly ash and $50 \%$ quarry dust) did not achieve the target strength at 28 days due to the delayed pozzolanic reactions. But it attains

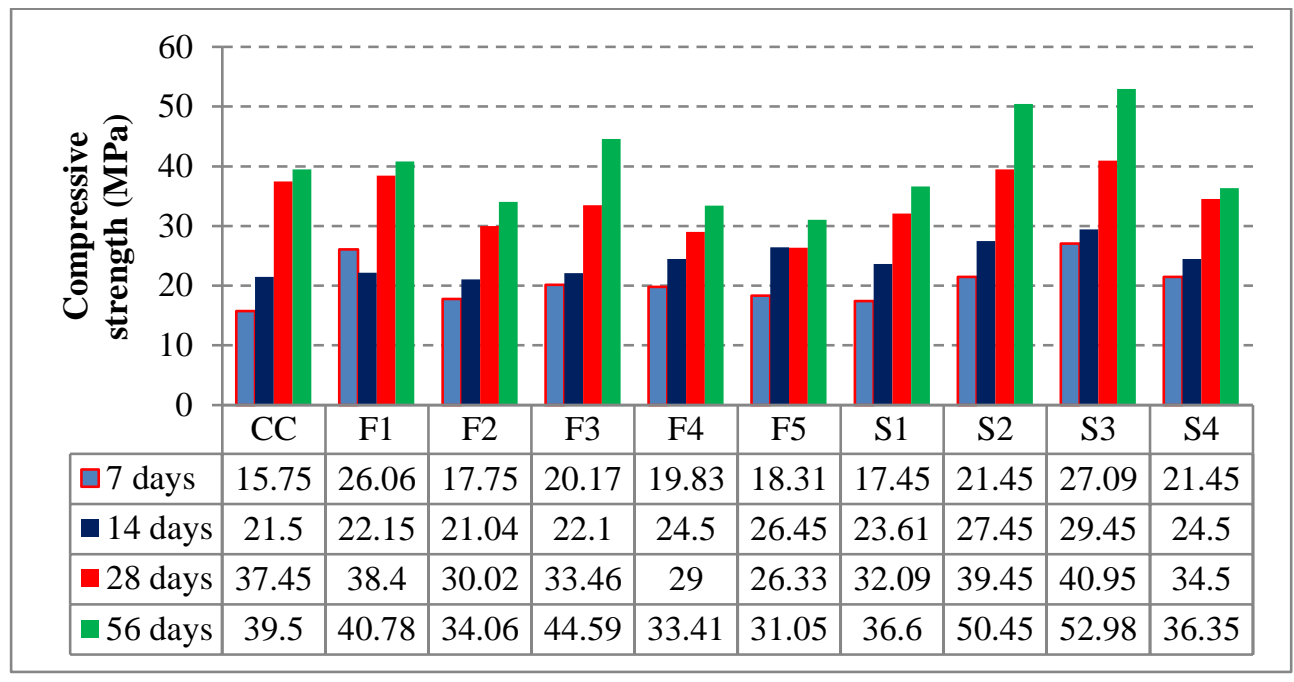

Fig. 4: Compressive Strength of Concrete for Various Mixes of Concrete.

More strength than that of the conventional concrete at the age of 56 days. Cement normally gains its maximum strength within 28 days. During the hydration process, fly ash together with lime produced from cement hydration imparts more strength. For this reason, concrete made with fly ash will have slightly lower strength than conventional concrete at early age of concrete and subsequently attains higher strength after 56 days. Fly ash decelerates the hydration of $\mathrm{C}_{3} \mathrm{~S}$ in the initial stages but accelerates it at later stages. It can be observed that the S3 mix (20\% fly ash, $10 \%$ micro silica and 50\% quarry dust) attains strength $33.92 \%$ greater than that of conventional concrete at the age of 56 days as shown in fig. 4 . The presence of quarry dust facilitates the filling of voids between coarse aggregates in concrete and makes concrete more compact and dense, thus raising the strength of concrete. Calcium hydroxide is released when the Portland cement in concrete begins to react chemically. The micro silica reacts with this calcium hydroxide to form additional binder material called calcium silicate hydrate which is very similar to the calcium silicate hydrate formed from Portland cement. It is an additional binder that gives silica-fume concrete its improved properties. Hence, the use of micro silica enhances the strength of the concrete.

\subsection{Split tensile strength of concrete}

It can be noted that the S3 specimen (20\% Fly ash, 10\% Micro silica and $50 \%$ quarry dust) attains strength $51.85 \%$ greater than that of the conventional concrete as shown in Fig. 5.

This is due to the fact that, through pozzolanic activity, fly ash combines with free lime to produce similar cementitious compounds formed by the hydration of Portland cement. It is due to this sequence of chemical reaction that the quantum of strength achievement for fly ash concrete is relatively slower at initial stages of curing. Moreover, micro silica dissolves in saturated solution of $\mathrm{Ca}(\mathrm{OH})_{2}$ within few minutes, which also contributes to the strength development in concrete.

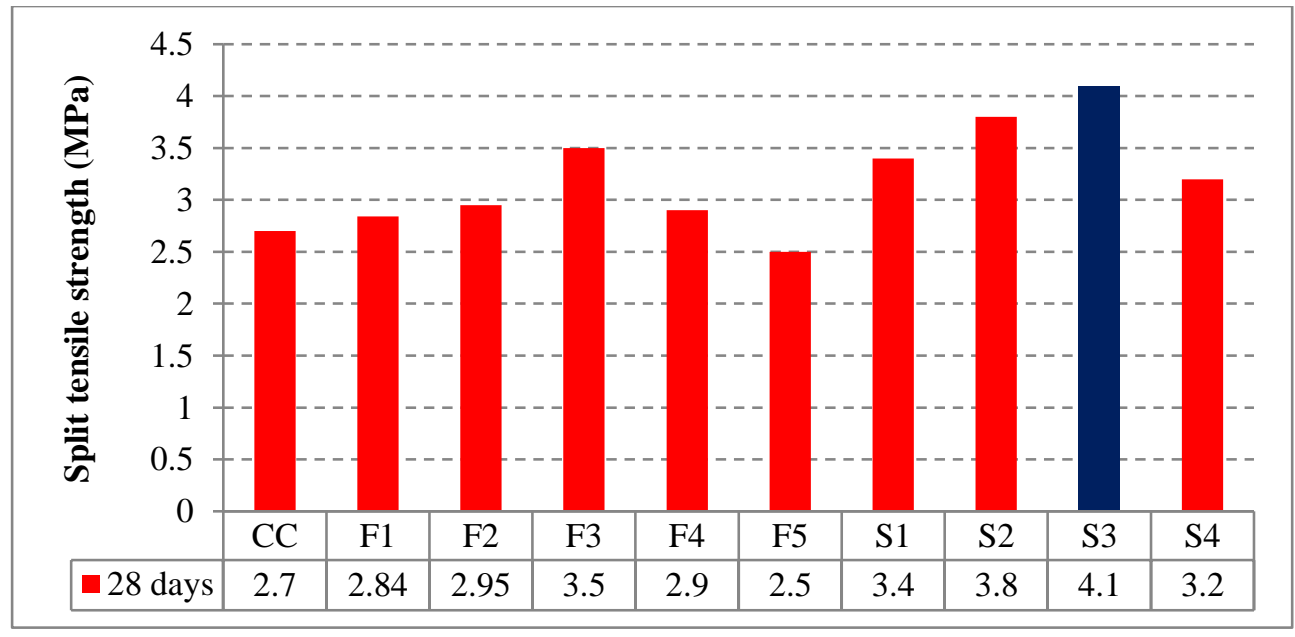

Fig. 5: Split Tensile Strength at Different Curing Days for Various Mixes of Concrete.

\subsection{Flexural strength of concrete}

The Ordinary Portland cement has hydrated to result in saturation of the pore water with $\mathrm{Ca}(\mathrm{OH})_{2}$. Calcium Silicate Hydrate $(\mathrm{C}-\mathrm{S}$ $\mathrm{H})$ gel is formed on the surface of micro silica particles, which 
contributes to the increased strength. The test results indicate that S3 mix (20\% fly ash, $10 \%$ micro silica and $50 \%$ quarry dust) attains strength of $48.28 \%$ more than that of the conventional concrete as shown in Fig. 6. Calcium silicate hydrate gel is formed from the hydration of cement, when calcium hydroxide is liberated as a result of the silica present due to the additon of micro silica.

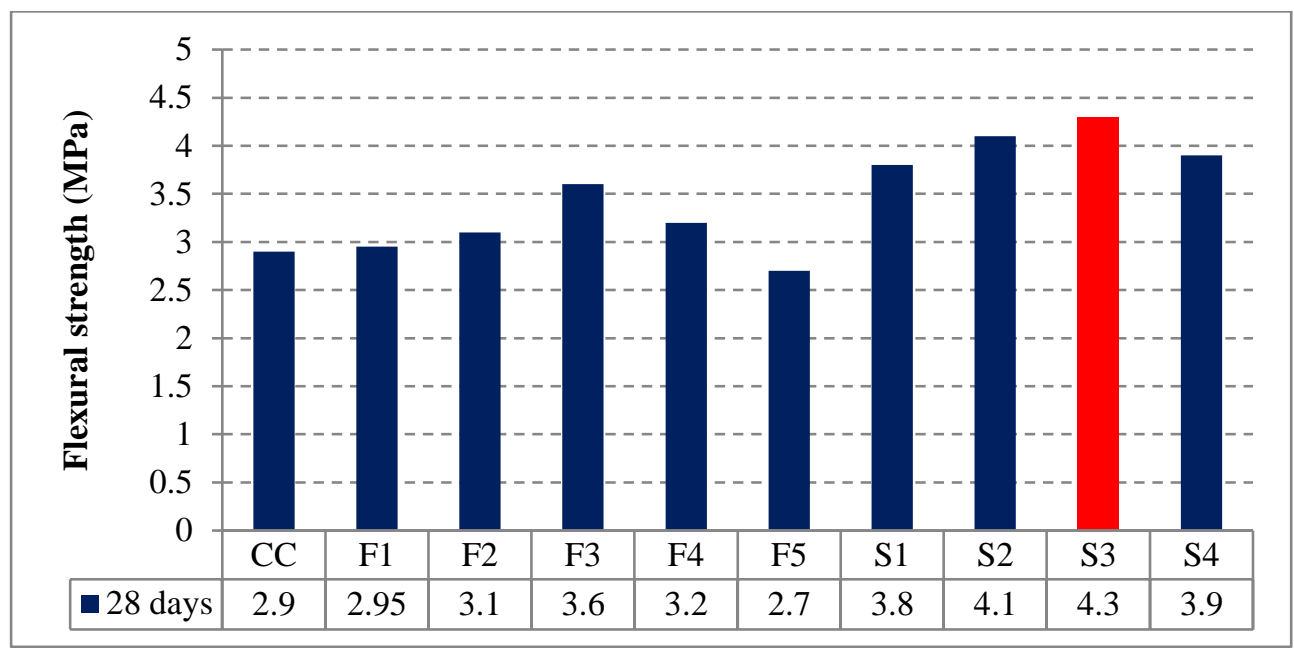

Fig. 6: Flexural Strength at Different Curing Days for Various Mixes of Concrete.

\subsection{Bond strength test}

The test results indicate that the mixes $\mathrm{F} 1$ (50\% quarry dust), F3(20\%fly ash and 50\% quarry dust) and S3(20\% fly ash,10\% micro silica and $50 \%$ quarry dust) mixes attain bond strengths of $10.20 \%, 9.7 \%$ and $32.10 \%$ respectively at the age of 56 days. This ideology proves that these types of pozzolona when added to the cement react to form a homogeneous paste of concrete and thereby improving the bonding capacity of concrete surrounding the rebars as shown in Fig. 7.

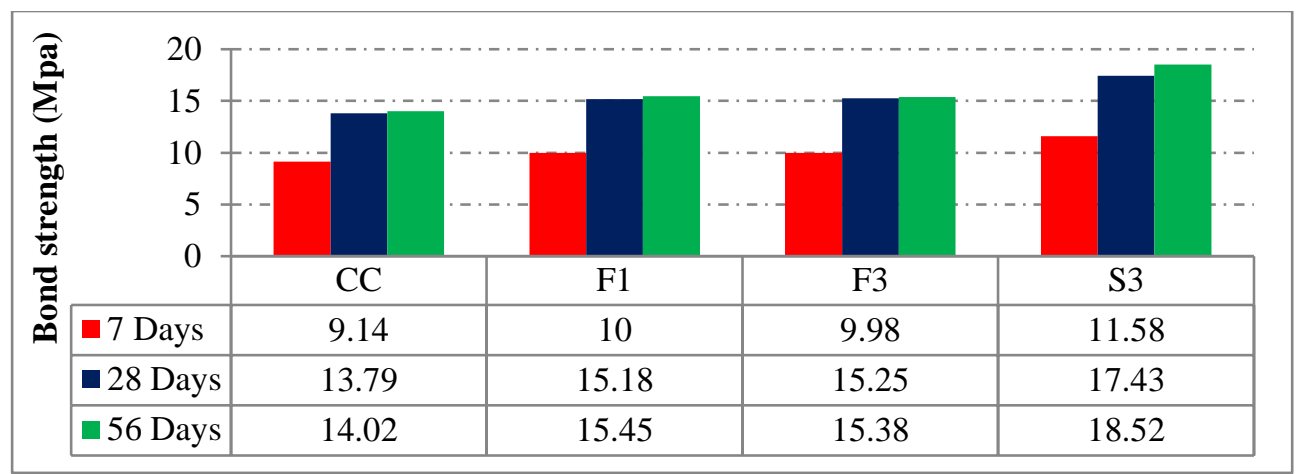

Fig. 7: Bond Strength of Concrete for Various Mixes.

\subsection{Modulus of elasticity of concrete test}

The experimental test results show that the young's modulus of conventional concrete (CC), fly ash blended concrete with quarry dust (F3), concrete containing hybrid mineral admixtures along with quarry dust $(\mathrm{S} 3)$ are $2.7 \times 10^{4} \mathrm{MPa}, 3.0 \times 10^{4} \mathrm{MPa}, 3.7 \times 10^{4}$ MPa respectively.

The specimen containing hybrid mineral admixtures and quarry dust (S3) possess higher modulus of elasticity when compared to conventional concrete. Hence, the concrete (S3 mix) is stiffer and more durable.

\subsection{Water permeability test}

Concrete cubes of $150 \mathrm{~mm}$ size were cast and cured for a period of 28 days. The surface of the cubes were wiped dry and placed in the water permeability Test apparatus as per DIN 1048 Part5 (1991) [15]. The compressor was started and the pressure was applied at a rate of $0.5 \mathrm{MPa}$ for 


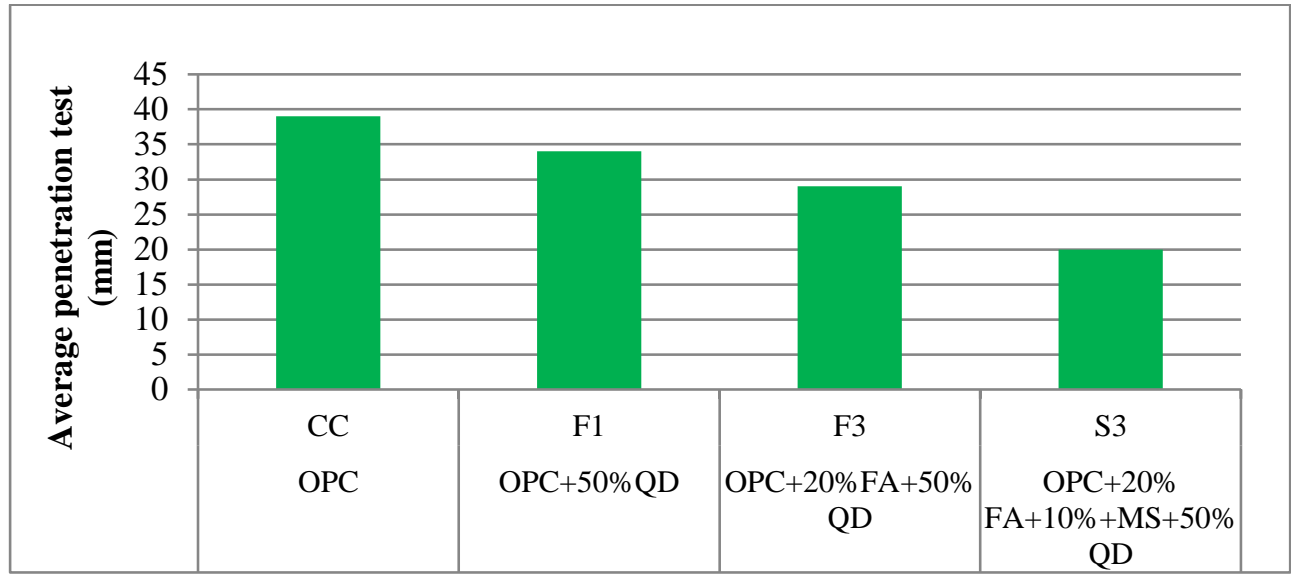

Fig. 8: Water Permeability Test for Various Mixes of Concrete.

A period of 72 hours. The specimens were later removed and split open. The actual penetration of water into the specimen was measured at three different points from the edges of the split cube and the average was found as $20 \%$ for S3 mix as shown in fig. 8 .

\subsection{Rapid chloride permeability test results}

One of the major important factors affecting the permeability inside the pore structure of the concrete depends upon the hydration of the pores gel in cementitious materials. The RCPT values for various mixes of concrete samples were tested at 28 and 90 days as per.

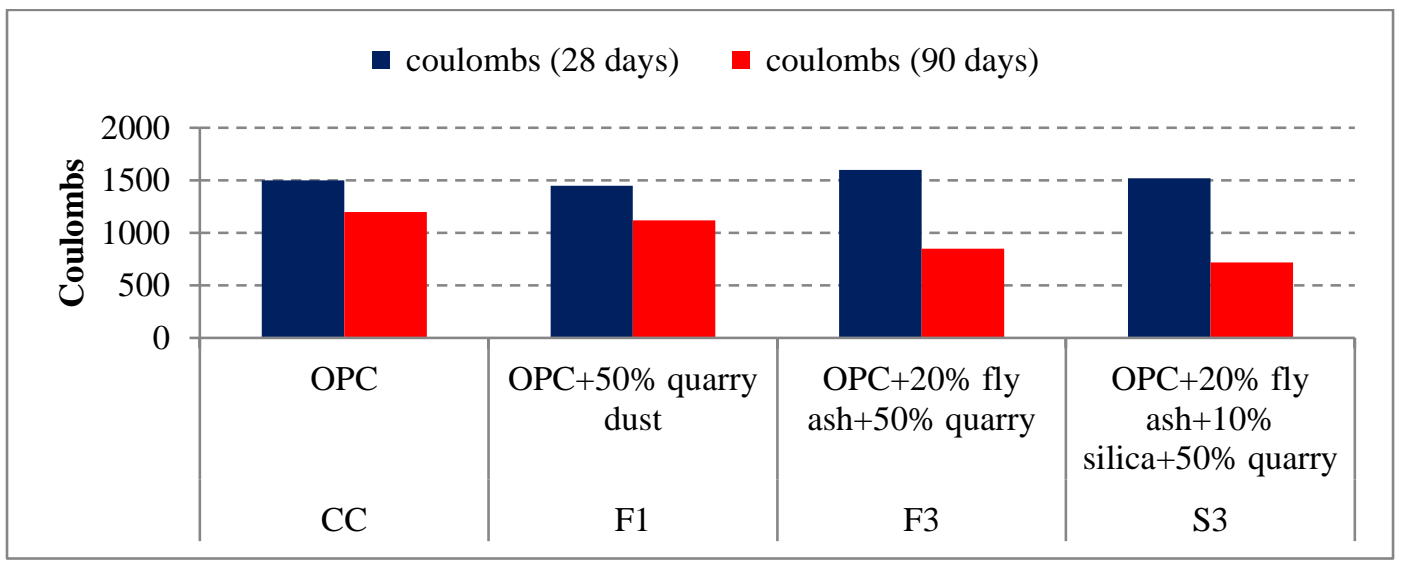

Fig. 9: RCPT Values for Various Mixes of Concrete at Age of 28 Days and 90 Days.

The code specifications of ASTM C 1202-97 [16]. A maximum of 1000 coulombs passed at 28 days as shown in Fig. 9. The samples were moist cured at all ages until the time of testing of concrete. RCPT was conducted on four different samples that had slight differences in the amounts of super plasticizer, fly ash, micro silica and quarry dust. It was also noted that these mixes did not reach the required 1000 coulombs passed at early age of 28 days. However, they attained the low permeability of concrete at later ages. At age of 90 days curing and later, there is almost no difference in chloride permeability among the various mixes tested.

\section{Conclusion}

The following conclusions can be drawn from experimental test results

- The presence of quarry dust $(50 \%)$ in the hybrid mineral admixture concrete decreases the workability and the desired workability is achieved by inclusion of chemical admixture (SNF)

- The slump values for concrete containing admixtures and quarry dust were more or less equal to slump value of conventional concrete.

- The concrete made with fly ash will have slightly lower strength than conventional concrete up to 28 days and substantially higher strength is achieved within 56 days. Fly ash decelerates the hydration of $\mathrm{C} 3 \mathrm{~S}$ in the initial stages but accelerates it at later stages.
- From the above test results the mix S3 (Fly Ash 20\% Micro silica $10 \%$ quarry dust $50 \%$ ) is of higher strength than the conventional concrete.

- Addition of Micro silica increases the chemical reaction that leads to silica gel formation, which gives more strength to concrete at early ages.

- Compressive strength increases with increase in percentage of micro silica up to $10 \%$ and further increase in micro silica did not increase the strength.

- The usage of cementitious materials and quarry dust in the construction industry helps to prevent the global warming and provide optimum exploitation of the resources.

\section{Acknowledgement}

The timely helps in terms of resources and suggestions from Dr. V.M. Sounthararajan, Professor in Civil Engineering, CMR Technical Campus and Dr.S. Sankaran, Professor in Civil Engineering, CMR Institute of Technology, Hyderabad is thankfully acknowledged.

\section{References}

[1] Aman Jatale and Kartikey Tiwari, Effects on compressive strength when cement is partially replaced by fly ash, IOSR Journal of Mechanical and Civil Engineering 5 (4) (2013) 34-43. https://doi.org/10.9790/1684-0543443. 
[2] Lam L A, Wong Y L A and Poon C S A, Effect of Fly Ash and Silica Fume on Compressive and Fracture Behaviors of Concrete, $\mathrm{Ce}$ ment and Concrete Research 28 (2) (1998) 271-283.

[3] Fuat Koksal , Fatih Altun , Ilhami Yigit and Yusa Sahin , Combined effect of silica fume and steel fiber on the mechanical properties of high strength concretes, Construction and Building Materi-

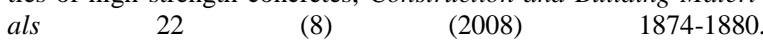
https://doi.org/10.1016/j.conbuildmat.2007.04.017.

[4] Siddique. R. Utilization of silica fume in concrete: review of hardened properties, Resources, Conservation and Recycling, 55 (2011) 923-932. https://doi.org/10.1016/j.resconrec.2011.06.012.

[5] Vikas Srivastava, Agarwal. V. C. and Rakesh Kumar, Effect of Silica fume on mechanical properties of concrete, Journal of Academia and Industrial Research, 1 (4) (2012) 176-179.

[6] Mohammad Iqbal Khan and Rafat Siddique, Utilization of silica fume in concrete: Review of durability properties, Resources, Conservation and Recycling, 57 (2011) 30-35. https://doi.org/10.1016/j.resconrec.2011.09.016.

[7] Bismark K. Meisuh, Charles K. Kankam and Thomas K. Buabin Effect of quarry rock dust on the flexural strength of concrete, Case Studies in Construction Materials, 8 (2018) 16-22. https://doi.org/10.1016/j.cscm.2017.12.002.

[8] IS 8112-1989 Indian Standard 43 grade Ordinary Portland cementSpecification, Bureau of Indian Standards, New Delhi, India.

[9] ASTM-C (1240-2000) Standard Specification for Micro silica used in Cementitious mixtures.

[10] IS 383:2016 Indian Standard Coarse and Fine Aggregate for Concrete-Specification, Bureau of Indian Standards, New Delhi, India.

[11] IS 2386(Part-I)-1963 Indian Standard methods of Test for aggregates for concrete Part-I Particle Size and Shape, Bureau of Indian Standards, New Delhi, India.

[12] IS 456-2000 Code of practice for plain and reinforced concrete structure.

[13] IS 10262 - 2009: Indian Standard Concrete Mix ProportioningGuidelines, Bureau of Indian Standards, New Delhi, India.

[14] IS 516-1959 Indian Standard Methods of Tests for Strength of concrete, Bureau of Indian Standards, New Delhi, India.

[15] DIN 1048 (Part 5): German Standard for determination of Concrete (1991).

[16] Standard Test Method for Electrical Indication of Concrete's Ability to Resist Chloride Ion Penetration," ASTM C 1202-97, Annual Book of ASTM Standards, 04(02), 639-644. 